\title{
Osmanlı İmparatorluğu'nda Modern Anlamda Yapılan İlk Nüfus Sayımı Verilerine Göre Antalya Kaleiçi Nüfusu Üzerine Demografik Bir İnceleme
}

\author{
A Demographic Assay into the Population of Kaleici, Antalya According to \\ Data from the First Modern General Census of the Ottoman Empire
}

\begin{abstract}
Aylin DOĞAN*
Öz: Nüfus üzerine yapılan araştırmalarla, bir toplumun hem sosyo-ekonomik, hem de sosyo-kültürel bir takım özellikleri hususunda önemli bilgiler elde edebilmek mümkündür. Bu çalışmanın amacı da, sadece müslüman erkek nüfusun sayıldığı, 1830'da başlayan ve 1831'de tamamlanan, Osmanlı İmparatorluğu'nun modern anlamda yapılan ilk genel nüfus sayımı verilerine göre, Antalya'daki yerleşimin çekirdek birimi olarak kaleiçi mahallelerindeki müslüman erkek nüfusun demografik açıdan incelenmesidir. $\mathrm{Bu}$ kayıtlardan sadece erkek nüfus sayısının tespiti açısından değil, diğer demografik unsurların tespiti açısından da yararlanılacaktır. Ayrıca, kayıtlarda yer alan sayım sonuçları ile kendi sayımlarımız neticesinde elde ettiğimiz sonuçlar arasındaki farklılık da ortaya konulacaktır. Başbakanlık Osmanlı Arşivleri tasnifinde 3190 numara ile yer alan, askeri maksat güdülerek müslüman erkek nüfusun sayıldığı ve Osmanlı Türkçesi ile kaydedilen Antalya'ya ait 1830 tarihli ilk genel nüfus sayım defteri (BOA., NFS.d. 3190), bu çalışmaya yön veren temel kaynak niteliğindedir. Bu çalışma ile ilk genel nüfus sayımı sonuçlarına göre Antalya Kaleiçi'nde tespit edilen 13 mahalledeki erkek nüfus verisi, demografik unsurlar açısından incelenerek, literatüre yeni veriler ışı̆̆ında bir katkı sunulması amaçlanmıştır.
\end{abstract}

Anahtar sözcükler: Osmanlı İmparatorluğu, İlk Genel Nüfus Sayımı, Antalya, Kaleiçi

Abstract: Through research on the population of a society, it is possible to obtain important information concerning both the socio-economic and socio-cultural aspects of that society. This study examines the male Muslim population of Kaleiçi, the oldest and the core settlement of Antalya, through the data obtained in the course of the first modern general census of the Ottoman state, begun in 1830 and completed in 1831, in which only data from the male population was taken. These records are employed not only to determine the number of the male population but also to determine other demographic elements. In addition, the differences between the census results that the records contain and our own census results are shown. The first general census book of Antalya dated 1830 (BOA, NFS.d.3190) containing the results of the census of the Muslim male population for military purposes was the primary source employed in this study with the aim of providing a contribution to the literature through examining the demographic elements recorded in the first general census of 13 neighbourhoods within Kaleiçi, Antalya.

Keywords: Ottoman Empire, First General Census, Antalya, Kaleiçi

Anadolu'da ilk Türk yerleşimleri, kaleler ve civarında gelişmiştir. Askeri unsurların ön planda olduğu Osmanlı İmparatorluğu'nda da kaleler, askeri açıdan olduğu kadar yerleşim açısından da önemli olmuşlardır. Fethedilen kalelere ilk iş olarak kale beyi, kadı, katip, imam ve muhafızlar

\footnotetext{
* Yrd. Doç. Dr., Harran Üniversitesi, İ.İ.B.F., İktisat/İktisatTarihi, Şanlıurfa, aylin_do@hotmail.com
} 
görevlendirilip, cami inşa edilerek veya mevcut kilise camiye çevrilerek, askeri güvenliğin sağlanması dışında, Türk-İslam unsurları taşıyan yerleşim yerlerinin oluşması sağlanmıştır (Acun, $2005,52)$. Kaleler, şehrin güvenliğinin sağlanması dışında adli ve idari olarak da önemli işlevlere sahip olmuşlardır.

14. yüzyıl sonlarında, Yıldırım Bayezid zamanında Osmanlı hakimiyetine geçen Antalya'da da (Erten, 1940, 84; Uzunçarş111, 1969, 68, 97; Tekindağ, 1979, 131; Karaca, 2002, 43-44) yerleşim, mevcut kale merkezli gelişmiş ve zaman içinde kale dışına doğru genişlemeye başlamıştır.

Çalı̧̧maya yön veren temel kaynak, Başbakanlık Osmanlı Arşivleri (BOA.) tasnifinde 3190 numara ile yer alan, askeri maksat güdülerek müslüman erkek nüfusun sayıldığı ve Osmanlı Türkçesi ile kaydedilen Antalya'ya ait 1830 tarihli ilk genel nüfus sayım defteridir. 1830'da başlayıp, 1831'de tamamlandığı için bu sayım, hem 1830 tarihi, hem de 1831 tarihi ile anılmaktadır. İncelemeye tabi tutulan 3190 numaralı, Antalya'ya ait ilk genel nüfus sayım defteri tarihi 1830 tarihini göstermekte olup, çalışmamızda bu tarih dikkate alınmıştır (BOA.,NFS.d. 3190). Defter verilerine göre, Antalya merkez kazasında 26 köy ve 34 mahalle sayıma tabi tutulmuş olup bu mahallelerden, 13'ü kaleiçinde (derun-i kal'a), 21'i ise kalenin dışında (haric-i kal'a) yer alan mahallelerdir. Çalışmanın kapsamı doğrultusunda, Antalya'ya ait 1830 tarihli ilkgenel nüfus sayımı sonuçlarına göre, Antalya Kaleiçi'nde tespit edilen 13 mahalledeki erkek nüfus verisi demografik unsurlar açısından tasnif edilerek ele alınmıştır.

Çalışmanın ilk bölümünde, genel olarak Osmanlı nüfus sayım geleneği ve ikinci bölümünde Antalya Kalesi ele alınmıştır. Üçüncü bölümde ise, 1830 tarihli, arşiv fonlarında, (BOA.,NFS.d. 3190) olarak kayıtlı olan Antalya'nın ilk genel nüfus sayım defteri kayıtlarına göre, Antalya Kaleiçi'nde tespit edilen 13 mahalleye ait erkek nüfus verisi demografik açıdan incelenmiştir. Elde edilen veriler, çalışmamızın sonuç bölümünde değerlendirilmiştir.

\section{Osmanlı İmparatorluğu'nda Nüfus Sayım Geleneği}

Osmanlı İmparatorluğu'nda, memleketin sayımına büyük önem verilmiş olup “nüfus, arazi ve mal" sayımlarını ihtiva eden bu sayımların, önemli siyasi teşekküllerin bulunduğu her yerde muntazam ve teferruatlı bir şekilde yapıldığı söylenebilir (Barkan, 2000, 181). Devlet, yapmış olduğu bu sayımlarla; mevcut halkın içinden askere alacağı, vergilendireceği ve diğer kamusal hizmetleri gördüreceği kişileri tespit etmeye çalışmıştır.

Memleketin sayımına verilen önem, Kemankeş Kara Mustafa Paşa'nın sadrazamlığı döneminde (1638-1643), Sultan İbrahim'e sunduğu bir layihadaki; "Tahrir: Memleket yazımı demektir. Gayet lazımdır. Otuz yılda bir kere tahrir-i memleket kanundur. Amma gayet Müslüman ve dindar adamlar tayin olunup cümle mahrusa bir uğruna tahrir lazımdır." İfadelerinde görülebildiği gibi, Defterdar Sarı Mehmet Paşa'nın; "Reayanın defteri dahi Divan-ı ali defterhanesinde mazbut olup otuz senede bir tahrir olunup mürde ve marizleri ifraz ve hariç ezdefter olanları müceddeten deftere kaydettirmek lazımdır" şeklindeki ifadelerinde de görülebilmektedir (Karal, 1943, 6).

Osmanlı İmparatorluğu'ndaki sayımlar, günümüzdeki gibi istatistiki ve ilmi tetkikler açısından veri elde etmek amacından ziyade, asker ve vergi toplamak amacıyla yapılmışlardır. Osmanlı öncesi Türk-İslam devletlerinde de büyük nüfus ve arazi sayımları yapılmış olup, Osmanlı Devleti de, yeni bir usul oluşturmak yerine eski Türk-İslam devletlerinden gelen usulü, değiştirerek ve geliştirerek devam ettirmiştir. Defterlerini Farisi olarak düzenleyen Selçuk Türklerinin aksine, Osmanlı Türkleri Türkçe kullanmışlardır. Özellikle devletin yükseliş dönemlerinde yazılan defterler, kullanılan malzeme, yazı ve düzen tekniği, tasnif usulleri ve fihrist düzeni gibi açılardan oldukça geliştirilmiştir. Ancak zamanla, dağılma dönemine giren devletin 
her alanında görülmeye başlayan yozlaşma, bu defterlerin yazılış ve muhafaza ediliş biçimlerinde de görülmeye başlamıştır (Barkan, 2000, 180-183).

Nüfusun asırlarca, asker ve vergi toplamak amaciyla sayıldığı Osmanlı İmparatorluğu'nda, bu yöndeki sayımların 16. yüzyılın ikinci yarısına, III. Murat devrine (1566-1574) kadar sürdüğü bilinmektedir. 17. yüzyıl başlarında, bir nüfus sayımı söz konusu olup bu yüzyılda, başkaca bir nüfus sayımı olmadığ 1 gibi, 18. yüzyılda da herhangi bir nüfus sayımı kaydı bulunmamaktadır. (Karal, 1943, 7). Bunda, 17. yüzyıldan itibaren devlet teşkilatının bozulmaya yüz tutması dolayısıyla sayımların başarıyla yerine getirilememesinin etkili olduğu söylenebilir (Barkan, 2000, 179).

19. yüzyılda ise birçok kez nüfus sayımı teşebbüsünde bulunulduğu ve bazen de kısmi veya külli nüfus sayımı yapıldığı bilinmektedir. II. Mahmut'un hükümdarlığg sırasında, 1829 yılında, doğrudan doğruya imparatorluktaki demografik yapının incelenmesine yönelik ilk nüfus sayımı teşebbüsü gerçekleştirilmiştir. 1829 'daki bu sayım, genel bir nüfus sayımı için bir nevi tecrübe niteliğinde olup, Osmanl1-Rus harbi dolayısıyla neticelendirilememiştir (Bingöl, 2004, 43-60). Bu sayım sonrasında, 1831 'de, 1844 'te ve yüzyıl sonlarına doğru küçük veya büyük farklı sayımlar gerçekleştirilmiştir (Karal, 1943, 7-10). Ancak, 1831 ve 1844 genel nüfus sayımları, yalnızca müslüman erkek nüfusun sayılması ve devlet sınırları içindeki her yeri kapsamamaları dolayısıyla, demografik unsurların devlet genelinde değerlendirilebilmeleri açısından tatmin edici sonuçlar vermekten uzaktır. En ayrıntılı ve en önemli nüfus sayımları, 19. yüzyıl sonları (1885) ve 20. yüzyıl başlarında (1907) gerçekleştirilen sayımlardır. Bu sayımlarda nüfus, yaşa, cinsiyete, medeni duruma, etnik ve dinsel duruma, mesleğe, doğum yerine ve diğer özelliklerine göre ayrılarak sayılmıştır. 1907'de gerçekleştirilen sayım sistemi, 20. yüzyıl boyunca gerçekleştirilen sayımların esasını oluşturmuştur (Elibol, 2007, 153-154).

1830 tarihli, Osmanlı İmparatorluğu'nun modern anlamda yapılan ilk genel nüfus sayımı, II. Mahmut dönemindeki yenileşme hareketleri doğrultusunda gerçekleştirilmiştir. Bu sayım için, 1830 Haziran ayından itibaren hazırlıklara başlanmış olup sayım, 1830 senesinin ikinci 6 ayı ve 1831 senesinin ilk 6 ayı içinde yapılmıştır. Mısır ve Arabistan'ın hariç tutulduğu bu sayımda, Anadolu ve Rumeli esas alınmıştır (Bingöl, 2004, 44). Her ne kadar sayım için hazırlanan mucip sebepler layihasında, nüfus sayımının askeri bir maksatla yapıldığı belirtilmemişse de, sayımda esasen böyle bir maksat güdülmüştür. Çünkü, 1826'da Yeniçeri Ocağı kaldırılmış ve derhal Asakir-i Mansure-i Mahmudiyye ismiyle yeni bir askeri birliğin oluşumu içine girilmiş, ancak, Yunan isyanları dolayısıyla başlayan Osmanlı-Rus harbi (1828-1829) bu girişimi mecburen kesintiye uğratmıştır. Savaşın ardından ise devlet, Anadolu ve Rumeli'den elde edebileceği askeri varlığı tespit edebilmek amacıyla nüfus sayımına girişmiş ve halk1 ürkütmemek için "matlubu aliye muvafik" (istenilene uygun) veya "mim işareti vaz olunan" (mim işareti konulan) etiketleri altında, askerliğe uygun kişileri kaydetmeye başlamıştır. Bu doğrultuda İslam nüfus genellikle, "matluba muvafik" (istenilene uygun) ve "matluba gayri muvafik" (istenilene uygun olmayan) olmak üzere, iki kısma ayrılarak yazılmıştır. Matluba gayri muvafık kısım içinde bazen ihtiyar, sabi, saka, amelmande diye, ikinci derecede ayrımlar da yapılmıştır (Karal, 1943, 18-19).

Görüldüğ̈̈ üzere, Osmanlı İmparatorluğu'nda doğrudan nüfusun esas alındığı, modern anlamdaki ilk genel nüfus sayımı gerçekleştirilmiş olsa da, yalnızca müslüman erkek nüfusun sayıldığı bu sayımda da yine, önceki sayımlarda olduğu gibi askeri amaç, sayımın temel amacını oluşturmuştur. Bu sayımlarda, Antalya ve diğer bazı yerlerde olduğu gibi, sadece müslüman nüfus sayılırken bazı yerlerde gayrimüslim nüfus da sayımlara dahil edilmiştir. 


\section{Antalya Kalesi}

Antalya Kalesi'nin, aynı zamanda șehrin kurucusu da olan Bergama hükümdarı II. Attalos Philadelphos tarafından, M.Ö. 158 yılında yaptırıldığı bilinmektedir (Armağan, 2005, 103). Antalya Kalesi'nde "Dış Kale", kaleyi dıştan çeviren surların içinde kalan bölümden oluşmakta olup askeri savunma amacıyla yapılmıştır. "IÇC Kale" ya da "hisar" ise, yöneticilerle maiyetinin oturdukları iç surların çevirdiği bölümden oluşmakta olup, hem askeri hem de idari ve mali amaçla kullanılmıştır (Özdemir, 1994, 1377).

Kalenin, egemenliğine girdiği devletler tarafından zaman zaman tamir ve takviye edilmiş olduğu görülmektedir (Armağan, 2005, 103). Hellenistik dönemde, limanı kuşatan ve doğuya doğru uzanan kesimde yer alan Antalya'ya, daha sonra güneydoğudaki geniş alan surlarla çevrilerek dahil edilmiştir. X. yüzyılda ise, kara tarafına ikinci bir sur ilave edilmiştir. Böylelikle, liman ve çevresi bir "iç kale" durumunda kalmış ve burası idarecilere ayrılmıştır. Tersaneyi kuşatan tarafta ikinci bir duvar inşa edilerek, tersane arkasındaki Ahi Yusuf Mescidi merkez olmak üzere bir yerleşim şeridi ortaya çıkmıştır. Arap seyyahların ifadelerinden öğrenildiği kadarıyla, Selçuklu Dönemi Antalyası etrafı üç kat surlarla çevrili, bağlık bahçelik, mamur bir şehir olup, ticaret limanı olması sebebiyle etnik açıdan karışık bir nüfusa sahip olmuştur. Selçuklular Dönemi'nde surlarla çevrili kapalı bir şehir olan Antalya, Osmanlı Dönemi'nde fiziki açıdan gelişerek sur dışına doğru genişlemeye başlamıştır. Çarşı ve pazarların sur dışında yer alması bu gelişmede etkili olmuştur (Emecen, 1991, 234).

Antalya Kalesi, Türk hakimiyetinin her döneminde önemli bir nokta olmuştur. Kalenin sıkl1kla tamir edilerek, elden geçirilmesi de bunun bir göstergesi niteliğindedir. Antalya Kalesi’nin Türkler tarafından tamiri, şehrin Selçuklular tarafından fethiyle başlamış olup kale, Beylikler Dönemi'nde de tamirden geçmiştir. Yine Osmanlılar zamanında da kale ve surlar muhtelif tarihlerde tamir edilmiştir (Armağan, 2005, 103).

Kalelerin tamiri hususuna büyük önem veren Osmanlı İmparatorluğu'nda, sık sık kale tamir keşfi yaptırılmış, devlete ait tamir edilen tüm kalelerin masrafları, sancaklara taksim edilerek tahsil edilmiştir (Moğol, 1990, 64). Antalya Kalesi de, dış surları, iç kalenin bazı bölümleri, birçok burç, kule ve tabyalar, cephanelik ve depolar, surlardan girişi sağlayan birçok kapı ve merdivenler, rıhtım ve iskelenin önemli yerleri olmak üzere ayrı ayrı tamir görmüştür. 19. yüzyılın ilk yarısında kalede yapılan tamiratlara yönelik bilgilerin, Antalya Şeri'yye Sicilleri'nde yer alan 1815, 1820, 1825, 1827, 1836 tarihli “Antalya Kalesi Tamirat Defterleri”inde kayıt altına alındığı görülmektedir (Özdemir, 1994, 1372-1380).

Bu defterlerin tanzim tarihlerine bakılırsa kalenin, 19. yüzyılın ilk yarısı itibariyle sıklıkla tamirattan geçtiği söylenebilir. Kalede sonraki tarihlerde de bir takım tamiratlar gerçekleştiği görülmekte olup 1846' da, kaledeki mevcut kısımların tamiratı dışında kaleye yeni kısımlar da eklendiği ve kalenin doğu kısmındaki duvarda yeni bir kapı açılarak, dışındaki hendek üzerine bir köprü inşasının söz konusu olduğu görülmektedir. Kaleye eklenen yeni kapı, köprü gibi kısımların inşasında, Antalya'daki yerleşik reaya nüfusun artışından dolayı, kale dışında da iskan yerlerinin oluşturulması amacı etkili olmuştur (Doğan, 2012, 69).

Belgelerden edinilen bilgiler, Antalya Kalesi'nde 19. yüzyılın ikinci yarısında da bir takım tamirat ve yeniliklere gidildiğini göstermektedir. Ayrıca, kale sınırları içinde bulunan arsa ve anbarların satıșlarının söz konusu olabildiği de görülmektedir. 3 Ocak 1851 ve 21 Ocak 1851 tarihli iki belge, Antalya Kalesi içinde bulunan bir arsanın satımına ilişkindir. Belgelerdeki ifadelere göre; bahsi geçen arsanın İbrahim Efendi adında birine satıldığı; ancak bunun mahzurundan dolayı, arsanın tekrar kale tarafından satın alınarak, kaleye katılması bildirilmektedir 
(BOA. A.AMD., 28-38, 3 Ocak 1851; BOA. A.MKT.MVL., 38-16, 21 Ocak 1851). 12 Eylül 1860 tarihli bir başka belgede ise; kale mühimmatının muhafazasına uygun bir ambar bulunmaması nedeniyle, sur içindeki miri ambarların satışından vazgeçilerek, tamir edilmek suretiyle kaleye teslim edilmesinin bildirildiği görülmektedir (BOA, A.MKT.MVL., 119-87, 12 Eylül 1860). Bu bilgiler aynı zamanda, yönetimin kale mühimmatının muhafazasına verdiği önemi de göstermektedir.

15 Kasım 1834 tarihli bir belgede, kale mühimmatıyla ilgili olarak şu bilgiler yer almaktadır: Antalya Kalesi'nde bulunmak üzere, Tophane-i Amire'den tertib edilen ve yollanması için irade buyrulan 9.500 yuvarlak dane (Dane: Gülle, Devellioğlu, 1999, 164) ile 50 adet küçük küfenin Feyzullah sefinesiyle ulaştığı, daneler ve küfelerin kale cephanesi müdürü Hüseyin'e teslim edilerek, kale cephanesine konulduğu bildirilmektedir (BOA, C.AS., 440-18313, 15 Kasım 1834). (Buna göre teslim edilen mühimmat şu şekildedir: Yuvarlak 5 müd olandan 3000; Yuvarlak 3 müd olandan 5000; Yuvarlak 1.5 müd olandan 500; Yuvarlak 1 müd olandan 1000), (Müd: Batman cinsinden bir ölçek, bk. Devellioğlu, 1999, 707) 4 Mart 1840 tarihli bir başka belgede ise; Antalya Kalesi'nde bulunan topların eski ve kullanılmaz halde olmaları nedeniyle, 14, 20 ve 24 çaplarında yeterli sayıda top ve topçu nefer gönderilmesinin bahsi geçmektedir (BOA. HAT., 1625-66, 4 Mart 1840). Belgelerden edindiğimiz bu bilgiler, Antalya Kalesi'nin mühimmat ve nefer açısından merkez tarafından desteklendiğini ve askeri açıdan da önemli bir kale niteliğinde olduğunu göstermektedir.

Yerleşim ve askeri hususlar dışında, Antalya Kalesi'nin adli açıdan da bir işleve sahip olduğu görülmektedir. Nitekim, diğer Osmanlı kalelerinde olduğu gibi Antalya Kalesi'nde de, idari görevlilerin de karıştı̆̆ kalpazanlık, rüşvet gibi bazı olayların neticesinde suçlular, "kalebend" olarak kalede mahpus edilmişlerdir. Mevcut örnekler, kalebendlik uygulamasının 19. yüzyılın ikinci yarısı itibariyle de devam ettiğini göstermektedir (Doğan, 2012, 70).

"İ̧̧ Kale" ve "Dış Kale" denilen surlarla çevrili Antalya Kalesi'nde, bu surların farklı yerlerine yapılan "Tophane, Hidirlık, Zindan, Liman" gibi burçlar vasıtasılla askeri amaçlar yerine getirilmeye çalışılırken, çeşitli kule, depo, idari binalar vasıtasıyla da, idari ve ticari amaçlar yerine getirilmeye çalışılmıştır (Özdemir, 1994, 1405). Kalede bu amaçların yerine getirilmesini "kale görevlileri" sağlamışlardır. Bu görevliler içinde; şehrin güvenliğinden sorumlu bir yönetici, timar sahibi olması dolayısıyla da bir asker olan "Kale Dizdarı" (Karaca, 2002, 82), devlete ait mallar ve kale hizmetleri hususunda kale dizdarının yardımcısı konumunda olan "Kale Kethüdası" (Moğol, 1990, 70) ve gece-gündüz kalenin güvenliğinin sağlanmasına yönelik hizmetlerde bulunan "Kale erleri, kale mühimmat müdiri ve derbendciler" yer almışlardır (Karaca, 2002, 85).

\section{Antalya'nın 1830 Tarihli İlk Genel Nüfus Sayım Defteri}

Teke Sancağı merkez kazası Antalya ve bağlı kazalarında, 1830 tarihli ilk genel nüfus sayım verilerini içeren nüfus defteri, Başbakanlık Osmanlı Arşivleri (B.O.A.) tasnifinde 1390 numara ile yer almaktadır. Sayım işlemi, Silahşorandan Hidayet Ağa sorumluluğunda gerçekleştirilmiştir.

Defter kayıtlarına göre sayım, merkez kazaya bağlı 26 köy ve 34 mahallede yapılmıştır. Defterin başlangıcında, "Teke sancă̆ında vaki nefs-i Antalya şehrinde mevcud nüfus defteri" ifadeleri yer almakta olup, nüfus sayımına Cami-i Cedid Mahallesi'nden başlandığı görülmektedir. Antalya'daki bu sayımda, yanlızca müslüman erkek nüfus sayıma tabi tutulmuş olup, kadın ve gayr-i müslim nüfus sayılmamıştır. Bu durumun, sayımın askeri amaçla yapılmasından ileri geldiği söylenebilir. Kayıtların başlangıcında öncelikle, Osmanlı toplumunda önderlik vasfına sahip olan mahallenin imamı ve yakınlarının kaydedildiği görülmektedir. Kişiler, babalarının 
isimlerine (Mustafa ibni Seyyid Mehmed/Seyyid Mehmed'in oğlu Mustafa gibi...), fiziksel özelliklerine, lakaplarına, yaş ve mesleki bilgilerine yer verilerek kaydedilmişlerdir. Kişiler kayıtlarda, kır sakallı, kara bıyıklı, ter bıyıklı, kumral bıyıklı, sarı bıyıklı, müzellef sakallı (tüyleri yeni çıkan), aksakallı, köse sakallı, uzun boylu, orta boylu, kısa boylu, yekçeşm (tek gözü olmayan), âmâ (kör), çolak (eli veya kolu sakat), bî-zeban (dilsiz), sağır vb. fiziksel özellikleri belirtilerek tasvir edilmişlerdir. Bazı kayıtlarda mesleki bilgilerin yer almadığı görülmekte olup, bunda nüfus sayımının askeri amaçla yapılmasından dolayı sayım esnasında, kişilerin mesleklerinin tamamen kaydedilmemiş olmasının etkili olduğu söylenebilir.

Kayıtlardan ayrıca, bir ailedeki mevcut erkek çocuk sayısı, herhangi bir fiziksel engele sahip olanlar (yekçeşm, âmâ, çolak, bî-zeban, sağır gibi), dışarıdan gelenlerin nereden geldikleri, kullanılan isimler ve soya, memlekete, mesleğe, fiziksel bir engel veya benzeri özelliklere dayanan çeşitli lakaplar hususunda da bilgiler edinilebilmektedir.

26 köy ve 34 mahallenin nüfus sayım sonuçlarını içeren defter kayıtlarında, her yerleşim birimine ait toplam sayım sonucu, o yerleşim biriminin sayım kaydı sonunda verilmekte olup, en sonda ise genel toplam verilmektedir. Çalışma konumuzun kapsamı doğrultusunda, Antalya'nın 1830 tarihli ilk genel nüfus sayım kayıtları, Antalya Kaleiçi'nde tespit edilen 13 mahalle bağlamında ele alınmıştır. Mevcut nüfus verileri, demografik unsurlar doğrultusunda tasnif edilmiş olup elde edilen sonuçlara aşağıdaki başlıklar altında yer verilmiştir.

\subsection{Tarihli İlk Nüfus Sayımına Göre Antalya Kaleiçi Mahallelerinde Demografik Yapı}

Osmanlı İmparatorluğu'nda modern anlamda yapılan ilk genel nüfus sayımında, Antalya'ya ait sayım sonuçları, 1830 tarihli nüfus defterinde kayıt altına alınmıştır. Belirtildiği üzere, bu kayıtlar, mevcut müslüman erkek nüfusun sayısı, yaş ve mesleki durumlarına yönelik bilgilerin yanı sıra, mevcut erkek nüfusa yönelik farklı bilgiler edinebilmemizi de sağlamaktadır. Bu sayede, 1830 senesinde Antalya Kaleiçi'nde tespit edilen mahallelerin, o tarihteki demografik yapısına yönelik bazı tespitlerde bulunulabilmek mümkün olmaktadır.

Defter kayıtlarına göre, Antalya kale içinde 13 mahalle tespit edilmiş olup bu mahalleler içinde: Cami-i Cedid, Cami-i Atik, Makbulağa, Hatib Süleyman, Mecdeddin, Has Balaban, Karadayı, İskender Çelebi, Baba Doğan, Tuzcular, Çullah Kara, Ahi Yusuf ve Ahi Kızı mahalleleri yer almaktadır. Antalya Kaleiçi'nde tespit edilen bu 13 mahallenin demografik açıdan incelenmesi de, defter kayıtlarının içerdiği veriler doğrultusundaki tasnife göre ele alınmıştır. Buna göre; elde edilen verilerin değerlendirilmesinde nüfus, sayı, yaş, mesleki durum ve nüfusa dair diğer özellikler dikkate alınarak bir tasnif yapılmıştır.

\subsubsection{Nüfus Sayımı Toplamları ve Nüfusa Dair Diğer Özellikler}

Burada, defter kayıtları doğrultusunda müslüman erkek nüfus sayısı ve yine bu kayıtların elverdiği ölçüde, belirlenen nüfusun sahip olduğu özellikler saptanmaya çalışılmıştır. Öncelikle mevcut nüfus rakamlarına bakacak olursak; Antalya'ya ait 1830 tarihli ilk nüfus defteri kayitlarına göre Antalya kale içinde sayımı yapılan 13 mahallede tespit edilen müslüman erkek nüfus sayısı aşağıdaki tabloda gösterilmiştir.

Tablo 1. 1830 Tarihli Nüfus Defteri Verilerine Göre Antalya Kale içinde Bulunan Mahallelerdeki Erkek Nüfus Sayıs1

\begin{tabular}{|c|l|c|}
\hline \multicolumn{2}{|c|}{ Mahalle İsimleri } & Erkek Nüfus Sayısı \\
\hline 1 & Mahalle-i Cami-i Cedid & 76 \\
\hline 2 & Mahalle-i Cami-i Atik & 74 \\
\hline
\end{tabular}




\begin{tabular}{|c|l|c|}
\hline 3 & Mahalle-i Makbulağa & $168-(173)$ \\
\hline 4 & Mahalle-i Hatib Süleyman & 52 \\
\hline 5 & Mahalle-i Mecdeddin & 59 \\
\hline 6 & Mahalle-i Has Balaban & 67 \\
\hline 7 & Mahalle-i Karadayı & 29 \\
\hline 8 & Mahalle-i İskender Çelebi & $57-(55)$ \\
\hline 9 & Mahalle-i Baba Doğan & 75 \\
\hline 10 & Mahalle-i Tuzcular & $72-(69)$ \\
\hline 11 & Mahalle-i Çullah Kara & 29 \\
\hline 12 & Mahalle-i Ahi Yusuf & $38-(37)$ \\
\hline 13 & Mahalle-i Ahi Kızı & 45 \\
\hline \multicolumn{2}{|l|}{ Toplam } & 841 \\
\hline
\end{tabular}

Kaynak: BOA., NFS.d. 3190

Bu tabloda yer alan toplamlara, defter kayıtlarındaki verilerin bizzat sayılması sonucunda ulaşılmıştır. Buna göre; 1830 senesinde Antalya kale içinde bulunan 13 mahalledeki toplam erkek nüfus sayısı 841 kişidir. Mevcut kadın nüfus da düşünüldüğünde, 13 mahallede toplam nüfusun 1.682 kişi olduğu tahmininde bulunulabilir.

Ancak, defter kayıtlarında toplam erkek nüfus sayısının 840 kişi olarak kaydedildiği görülmektedir. Bu farklılık ise, Makbulağa, İskender Çelebi, Tuzcular ve Ahi Yusuf mahallelerine ait kayıtlardaki toplamların farklılığından ileri gelmektedir. Makbulağa Mahallesi’nde defter kayıtlarına göre 173 kişi, kendi sayımlarımıza göre 168 kişi; İskender Çelebi Mahallesi'nde defter kayıtlarına göre 55 kişi, kendi sayımlarımıza göre 57 kişi; Tuzcular Mahallesi'nde defter kayıtlarına göre 69 kişi, kendi sayımlarımıza göre 72 kişi; Ahi Yusuf Mahallesi'nde defter kayıtlarına göre 37 kişi, kendi sayımlarımıza göre 38 kişi tespit edilmiştir. Tablo 1'de, parantez içinde belirtilen rakamlar, defter kayıtlarında yer alan toplamlar olup, bizim kendi sayımlarımız neticesinde ulaştığımız toplamlarla örtüşmemektedir. $\mathrm{Bu}$ da, sayım sonuçlarında rakamsal hataların söz konusu olabildiğini göstermektedir.

Defter verilerinin sayımı sonucunda oluşturulan yukarıdaki tablo verilerine göre; toplamı 841 kişiyi bulan Antalya Kaleiçi mahallelerinde, sayımı yapılan erkek nüfusun en fazla olduğu yer, 168 kişi ile Makbulağa mahallesidir. Ardından ise, 76 kişi ile Cami-i Cedid ve 75 kişi ile Baba Doğan mahalleleri gelmektedir. 29 kişinin bulunduğu Karadayı ile Çullah Kara mahalleleri ise, erkek nüfusun en az tespit edildiği mahallelerdir. Mahallelerdeki erkek nüfus sayıs1 açısından; Cami-i Cedid, Cami-i Atik, Makbulağa, Hatib Süleyman, Mecdeddin, Has Balaban, İskender Çelebi, Baba Doğan, Tuzcular mahalleleri olmak üzere, 9 mahalledeki erkek nüfusun 50 kişinin üzerinde olduğu; Karadayı, Çullah Kara, Ahi Yusuf ve Ahi Kızı mahalleleri olmak üzere 4 mahalledeki erkek nüfusun ise 50 kişinin altında olduğu görülmektedir.

Burada, mevcut erkek nüfus sayısı ile ilgili olarak şunu da belirtmek gerekir ki: Müslüman erkek nüfusun sayıldığı bu ilk genel nüfus sayımı, halk tarafından tereddütle karşılanmış olup nüfus adedine göre her vilayet, liva ve kazaya hükümetin teklifler yükleyeceği şayiası ortaya çıkmıştır. Bu şaiyanın etkisiyle, halk tarafından çoğu yerde erkek nüfus adedi daha az gösterilmek istenmiş̧tir (Karal, 1943, 9). Bu nedenle, mevcut sayım sonuçlarında, az ya da çok eksik kayıtların var olabileceği hatırlatılmalıdır.

Fiziksel özellik olarak, kişilerin kısa boylu, orta boylu ve uzun boylu oluşlarına göre yapılan 
tasvirler doğrultusunda tutulan kayıtlardan, genel olarak erkek nüfusun boy dağılımı ile ilgili bilgiler de edinilebilmektedir. Sayımlarda boy özelliklerinin de kaydedilmesinin, asker toplama amacıyla ilişkili olduğu düşünülebilir. Ancak kayıtlarda, kısa boylu, orta boylu veya uzun boylu ayrımının, hangi boy uzunluklarına göre yapıldı ğı konusunda herhangi bir kayıt bulunmamaktadır. Bu nedenle de, kaydedilen boy tanımlamalarıyla hangi boy uzunluklarının kast edildiği hususunda bir bilgi edinilememiştir. Boy dağılımı ile ilgili olarak elde edilen veriler doğrultusunda oluşturulan tablo aşağıda yer almaktadır.

Tablo 2. 1830 Tarihli Nüfus Defteri Verilerine Göre Antalya Kale içinde Bulunan Mahallelerdeki Erkek Nüfusun Boy Dağılımı

\begin{tabular}{|l|l|c|c|c|c|c|c|c|}
\hline \multicolumn{2}{|l|}{ Mahalle İsimleri } & $\begin{array}{l}\text { Kisa } \\
\text { Boylu } \\
\text { (Kişi) }\end{array}$ & $\begin{array}{c}\text { Yüzde } \\
(\%)\end{array}$ & $\begin{array}{c}\text { Orta } \\
\text { Boylu } \\
(\text { Kişi) }\end{array}$ & $\begin{array}{c}\text { Yüzde } \\
(\%)\end{array}$ & $\begin{array}{c}\text { Uzun } \\
\text { Boylu } \\
(\text { Kişi) }\end{array}$ & $\begin{array}{c}\text { Yüzde } \\
(\%)\end{array}$ & $\begin{array}{c}\text { Toplam } \\
\text { (Kişi) }\end{array}$ \\
\hline 1 & Mahalle-i Cami-i Cedid & 1 & 2,5 & 29 & 72,5 & 10 & 25 & 40 \\
\hline 2 & Mahalle-i Cami-i Atik & 5 & 11 & 37 & 80 & 4 & 9 & 46 \\
\hline 3 & Mahalle-i Makbulağa & 3 & 3,571 & 62 & 73,81 & 19 & 22,61 & 84 \\
\hline 4 & $\begin{array}{l}\text { Mahalle-i Hatib } \\
\text { Süleyman }\end{array}$ & - & 0 & 26 & 93 & 2 & 7 & 28 \\
\hline 5 & Mahalle-i Mecdeddin & 2 & 7 & 23 & 82 & 3 & 11 & 28 \\
\hline 6 & Mahalle-i Has Balaban & 3 & 7 & 27 & 63 & 13 & 30 & 43 \\
\hline 7 & Mahalle-i Karadayı & - & 0 & 12 & 71 & 5 & 29 & 17 \\
\hline 8 & $\begin{array}{l}\text { Mahalle-i İskender } \\
\text { Çelebi }\end{array}$ & 1 & 4 & 24 & 89 & 2 & 7 & 27 \\
\hline 9 & Mahalle-i Baba Doğan & 3 & 7,31 & 28 & 68,29 & 10 & 24,39 & 41 \\
\hline 10 & Mahalle-i Tuzcular & 3 & 9 & 19 & 58 & 11 & 33 & 33 \\
\hline 11 & Mahalle-i Çullah Kara & - & 0 & 11 & 85 & 2 & 15 & 13 \\
\hline 12 & Mahalle-i Ahi Yusuf & 3 & 15 & 16 & 80 & 1 & 5 & 20 \\
\hline 13 & Mahalle-i Ahi Kızı & - & 0 & 17 & 77 & 5 & 23 & 22 \\
\hline Toplam & 24 & 5 & 331 & 75 & 87 & 20 & 442 \\
\hline
\end{tabular}

Kaynak: BOA.,NFS.d. 3190

Yukarıda yer alan tabloya göre; 841 kişinin kayıtlı olduğu defter verilerinde, boy özellikleri itibariyle kaydedilen toplam kişi sayısı 442'dir. Bu toplam içinde sırasıyla; orta boylu kişi sayısı 331, uzun boylu kişi sayısı 87 ve kısa boylu kişi sayısı 24 kişi olarak tespit edilmiştir. Boy özellikleri verilen genel toplam içinde, orta boylu kişiler \%75, uzun boylu kişiler \%20 ve kısa boylu kişiler \% $\%$ 'lik bir paya sahiptir. Bu da, nüfusun genel olarak orta boylu bir yapı sergilediğini göstermektedir. Belirtildiği üzere kayıtlarda, boy değerlendirmesinin hangi kriterlere göre yapıldığı konusunda herhangi bir bilgi bulunmamaktadır.

Tablo verilerine mahalleler açısından bakıldığında; Hatib Süleyman, Karadayı, Çullah Kara ve Ahi Kızı mahallelerinde kısa boylu kişi olmadığı görülmektedir. Mahalleler içinde kişi sayısı olarak, orta boylu ve uzun boylu kişi sayısının en yüksek olduğu yer (ortaboylu: 62 kişi ve uzun boylu: 19 kişi) Makbulağa Mahallesi, kısa boylu kişi sayısının en yüksek olduğu yer ise (5 kişi) Cami-i Atik mahallesidir. Orta boylu kişi sayısının en az olduğu yer (11 kişi) Çullah Kara Mahallesi, uzun boylu kişi sayısının en az olduğu yer (1 kişi) Ahi Yusuf Mahallesi, kısa boylu 
kişi sayısının en az olduğu yerler ise, (1 kişi) Cami-i Cedid ve İskender Çelebi mahalleleridir.

Mahallelerdeki boy dağılımına, en yüksek ve en düşük yüzde değerler açısından bakıld1ğında ise; orta boylu kişiler yüzdesinin en yüksek olduğu yer \%93'lük bir oranla Hatib Süleyman Mahallesi, uzun boylu kişiler yüzdesinin en yüksek olduğu yer \%33'lük bir oranla Tuzcular Mahallesi ve kısa boylu kişiler yüzdesinin en yüksek olduğu yer \%15'lik bir oranla Ahi Yusuf Mahallesi'dir. Orta boylu kişiler yüzdesinin en düşük olduğu yer ise \%58'lik bir oranla Tuzcular Mahallesi, uzun boylu kişiler yüzdesinin en düşük olduğu yer \%5'lik bir oranla Ahi Yusuf Mahallesi ve kısa boylu kişiler yüzdesinin en düşük olduğu yer \%2,5'lik bir oranla Cami- Cedid Mahallesi'dir. Hatib Süleyman, Karadayı, Çullah Kara ve Ahi Kızı mahallelerinde ise kısa boylu kişi kaydına rastlanmamıştır.

Defter kayıtlarından, sayımı yapılan toplam erkek nüfus içinde, Antalya’ya farklı yerlerden gelenlerin olduğu da görülebilmektedir. Antalya Kaleiçi mahallelerindeki dışarıdan gelen kişi sayısı ve geldikleri yerler aşağıda bir tablo halinde gösterilmiştir.

Tablo 3. 1830 Tarihli Nüfus Defteri Verilerine Göre Antalya Kaleiçi Mahallelerine Farklı Yerlerden Gelen Kişi Sayısı ve Geldikleri Yer

\begin{tabular}{|c|c|c|}
\hline \multicolumn{2}{|r|}{ Mahalle İsimleri } & Dışarıdan Gelen Kişi Sayısı ve Geldikleri Yer \\
\hline 1 & Mahalle-i Cami-i Cedid & 1 (Burdurlu) \\
\hline 2 & Mahalle-i Cami-i Atik & 8 (1 Edirneli- 4 Bağdadi- 1 Tokadl1- 1 Hamidli- 1 İskenderani) \\
\hline 3 & Mahalle-i Makbulağa & $\begin{array}{l}9 \text { (1 Anamurlu- } 1 \text { Ünyeli- } 1 \text { İstanköylü- } 1 \text { Bursalı- } 1 \text { Karadeniz } \\
\text { Ereğlisinden- } 1 \text { Kıbrısl1- } 2 \text { İskenderiyeli- } 1 \text { Alaiyyeli) }\end{array}$ \\
\hline 4 & Mahalle-i Hatib Süleyman & 1 (İskenderani) \\
\hline 5 & Mahalle-i Mecdeddin & - \\
\hline 6 & Mahalle-i Has Balaban & - \\
\hline 7 & Mahalle-i Karadayı & - \\
\hline 8 & Mahalle-i İskender Çelebi & 2 (1 Tosyal1- 1 İskenderani) \\
\hline 9 & Mahalle-i Baba Doğan & - \\
\hline 10 & Mahalle-i Tuzcular & $\begin{array}{l}6 \text { (1 İskenderani- } 1 \text { Misırlı- } 1 \text { Trabzoni- } 1 \text { Rodoslu- } 1 \\
\text { Çanakkalal1- } 1 \text { Alaiyyeli) }\end{array}$ \\
\hline 11 & Mahalle-i Çullah Kara & 1 (Gazzeli) \\
\hline 12 & Mahalle-i Ahi Yusuf & $\begin{array}{l}8 \text { (1 Giridli- } 2 \text { İskenderiyeli- } 2 \text { Alaiyyeli- } 1 \text { Konyal1- } 1 \text { İznikmidli- } \\
1 \text { Misırlı) }\end{array}$ \\
\hline 13 & Mahalle-i Ahi Kızı & 1 (Mihaliçli) \\
\hline \multicolumn{2}{|c|}{ Toplam } & 37 kişi \\
\hline
\end{tabular}

Kaynak: BOA.,NFS.d. 3190

Tablo verilerine bakıldığında; sayımı yapılan mevcut erkek nüfus içinde tespit edilen 37 kişinin farklı yerlerden geldikleri görülmektedir. Farklı bir yerden gelenlerin sayısının en yüksek olduğu mahalleler Makbulağa (9 kişi), Cami-i Atik (8 kişi) ve Ahi Yusuf (8 kişi) mahalleleridir. Mecdeddin, Has Balaban, Karadayı ve Baba Doğan mahallelerinde ise farklı bir yerden gelen kişilere rastlanmamıştır. Antalya'ya dışarıdan gelenlerin, farklı farklı yerlerden geldikleri görülmekte olup İskenderiyeli olanların (yani Mısır'dan gelenlerin), diğerlerine göre sayıca daha fazla oldukları tespit edilmiştir. Defter verileri doğrultusunda, Antalya Kaleiçi mahallelerindeki toplam erkek nüfus içinde, herhangi bir fiziksel engele sahip olanları tespit edebilmek de mümkün olup, elde edilen sonuçlara aşağıdaki tabloda yer verilmiştir. 
Tablo 4. 1830 Tarihli Nüfus Defteri Verilerine Göre Antalya Kaleiçi Mahallelerindeki Engelli Kişi Sayısı ve Mevcut Engelleri

\begin{tabular}{|c|l|l|}
\hline \multicolumn{2}{|c|}{ Mahalle İsimleri } & \multicolumn{1}{|c|}{ Engelli Kişi Sayısı ve Engeli } \\
\hline 1 & Mahalle-i Cami-i Cedid & - \\
\hline 2 & Mahalle-i Cami-i Atik & 1 (Yekçeşm) \\
\hline 3 & Mahalle-i Makbulağa & 3 (2 alil- 1 çolak) \\
\hline 4 & Mahalle-i Hatib Süleyman & 2 (Yekçeşm) \\
\hline 5 & Mahalle-i Mecdeddin & - \\
\hline 6 & Mahalle-i Has Balaban & 2 (1 Yekçeşm- 1 alil) \\
\hline 7 & Mahalle-i Karadayı & 2 (bî-zeban) \\
\hline 8 & Mahalle-i İskender Çelebi & - \\
\hline 9 & Mahalle-i Baba Doğan & 1 (âmâ) \\
\hline 10 & Mahalle-i Tuzcular & - \\
\hline 11 & Mahalle-i Çullah kara & 1 (sağır) \\
\hline 12 & Mahalle-i Ahi Yusuf & - \\
\hline 13 & Mahalle-i Ahi Kızı & 2 (alil) \\
\hline Toplam & 14 kişi \\
\hline
\end{tabular}

Kaynak: BOA.,NFS.d. 3190

Tabloda da görüleceği üzere, toplam erkek nüfus içinde bir fiziksel engeli olan 14 kişi tespit edilmiş olup, engelli kişi sayısının, toplamı 841'i bulan erkek nüfus içindeki payı \% 1.66'dır. Cami-i Cedid, Mecdeddin, İskender Çelebi, Tuzcular, Ahi Yusuf ve Ahi Kızı mahallelerinde engelli bir kişiye rastlanmazken, kalan diğer mahallelerde; yekçeşm (tek gözü olmayan), âmâ (kör), alil (kör, sakat), çolak (eli veya kolu sakat), bî-zeban (dilsiz), sağır gibi fiziksel bir engeli olan kişiler tespit edilmiştir. Defter verilerinin elverdiği ölçüde, kişilerin sahip oldukları erkek çocuk sayısı da tespit edilebilmektedir. Bununla ilgili elde edilen veriler aşağıdaki tabloda yer almaktadir.

Tablo 5. 1830 Tarihli Nüfus Defteri Verilerine Göre Antalya Kale içinde Bulunan Mahallelerdeki Kişilerin Erkek Çocuk Sayısı

\begin{tabular}{|c|c|c|c|c|c|c|c|c|}
\hline & Mahalle İsimleri & $\begin{array}{l}\text { Nüfus } \\
\text { Miktarı }\end{array}$ & $\begin{array}{c}1 \\
\text { çocuğu } \\
\text { olan }\end{array}$ & $\begin{array}{c}2 \\
\text { çocuğu } \\
\text { olan }\end{array}$ & $\begin{array}{c}3 \\
\text { çocuğu } \\
\text { olan }\end{array}$ & $\begin{array}{c}4 \\
\text { çocuğu } \\
\text { olan }\end{array}$ & $\begin{array}{c}5 \\
\text { çocuğu } \\
\text { olan }\end{array}$ & $\begin{array}{c}6 \\
\text { çocuğu } \\
\text { olan }\end{array}$ \\
\hline 1 & Mahalle-i Cami-i Cedid & 76 & 4 kişi & 9 kişi & 5 kişi & 2 kişi & - & - \\
\hline 2 & Mahalle-i Cami-i Atik & 74 & 7 kişi & 7 kişi & 3 kişi & 1 kişi & - & - \\
\hline 3 & Mahalle-i Makbulağa & 168 & 15 kişi & 18 kişi & 6 kişi & 3 kişi & - & 1 kişi \\
\hline 4 & $\begin{array}{l}\text { Mahalle-i Hatib } \\
\text { Süleyman }\end{array}$ & 52 & 4 kişi & 6 kişi & 3 kişi & 2 kişi & - & - \\
\hline 5 & Mahalle-i Mecdeddin & 59 & 3 kişi & 8 kişi & 4 kişi & - & 1 kişi & - \\
\hline 6 & Mahalle-i Has Balaban & 67 & 11 kişi & 7 kişi & 3 kişi & 2 kişi & - & - \\
\hline 7 & Mahalle-i Karadayı & 29 & 4 kişi & 2 kişi & - & 1 kişi & - & - \\
\hline 8 & $\begin{array}{l}\text { Mahalle-i İskender } \\
\text { Çelebi }\end{array}$ & 57 & 9 kişi & 5 kişi & 2 kişi & 1 kişi & - & - \\
\hline
\end{tabular}




\begin{tabular}{|c|l|c|c|c|c|c|c|c|}
\hline 9 & Mahalle-i Baba Doğan & 75 & 8 kişi & 12 kişi & 3 kişi & - & 1 kişi & - \\
\hline 10 & Mahalle-i Tuzcular & 72 & 9 kişi & 9 kişi & 3 kişi & - & - & 1 kişi \\
\hline 11 & Mahalle-i Çullah Kara & 29 & 1 kişi & 4 kişi & 1 kişi & - & - & - \\
\hline 12 & Mahalle-i Ahi Yusuf & 38 & 5 kişi & 3 kişi & 1 kişi & - & - & - \\
\hline 13 & Mahalle-i Ahi Kızı & 45 & 6 kişi & 10 kişi & 1 kişi & - & - & - \\
\hline \multicolumn{2}{l|}{ Toplam } & 841 & 86 & 100 & 35 & 12 & 2 & 2 \\
\hline
\end{tabular}

Kaynak: BOA.,NFS.d. 3190

Tablo verilerine göre; mevcut erkek nüfusun 841 kişi olduğu Antalya Kaleiçi mahallelerinde erkek çocuğu olan kişi sayısı, yani "baba sayısı" 237'dir. Sahip olunan erkek çocuk sayısı olarak 1 çocuğu olan 86 kişi, 2 çocuğu olan 100 kişi, 3 çocuğu olan 35 kişi, 4 çocuğu olan 12 kişi, 5 çocuğu olan 2 kişi ve 6 çocuğu olan yine 2 kişi tespit edilmiştir. Bu 237 kişi içinde sirasıyla; 2 erkek çocuğu olan, 1 erkek çocuğu olan ve 3 erkek çocuğu olan kişi sayısı daha fazla çıkmış olup 1, 2 ve 3 erkek çocuğu olan kişilerin toplamı, mevcut toplamın \% 93'ünü, 4, 5 ve 6 erkek çocuğu olan kişilerin toplamı ise mevcut toplamın \% 7'sini oluşturmaktadır.

Osmanlı aile yapısının temelde, çekirdek aile özellikleri taşıdığı yönünde kabul gören bir görüş söz konusudur. Osmanlı ailesinin çok çocuklu olanları istisna olup çoğunluğu sirasıyla, 1 , 2 ve 3 çocuklu aileler oluşturmaktadır (Tabakoğlu, 2003, 152). Kayıtlardan, kız çocuk sayısı ile ilgili herhangi bir bilgi edinilememekle birlikte, bu genel görüşten ve tespit edilen mevcut verilerden hareketle, Antalya Kaleiçi mahallelerindeki aile yapısının da tipik Osmanlı çekirdek aile yapısı ile örtüştüğü söylenebilir. Yine, geleneksel Osmanlı aile yapısının, günümüz modern çekirdek aile yapısı ile benzeştiğini söylememiz de mümkündür.

Kayıtlardan anlaşıldığı kadarıyla, çocuklara dedelerinin ismini verme geleneğinin yaygın olduğu görülmekle birlikte, babalarının isimlerinin verildiği de görülmektedir. (Yusuf ibni Yusuf vb.) Dede veya baba ismi, genellikle büyük çocuk veya küçük çocuklara verilmekte olup bazı kayıtlarda, ortanca çocukların da dede veya baba ismi ile adlandırıldıkları tespit edilmiştir.

Toplam nüfus içinde kullanılan isimlere yaygınlık açısından bakıldığında, en yaygın kullanılan isimler, mahallelerdeki sayıları itibariyle aşağıdaki tabloda gösterilmiştir.

Tablo 6. 1830 Tarihli Nüfus Defteri Verilerine Göre Antalya Kaleiçi Mahallelerinde Yaygın Olarak Kullanilan İsimler

\begin{tabular}{|c|c|c|c|c|c|c|c|c|c|c|c|c|c|c|c|}
\hline Mahalle İsimleri & $\begin{array}{l}\vec{D} \\
\stackrel{\Xi}{E} \\
\end{array}$ & $\bar{Z}$ & 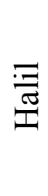 & 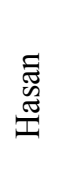 & 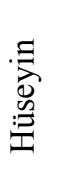 & 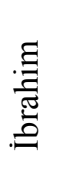 & 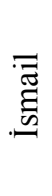 & $\begin{array}{l}\text { D } \\
\text { E } \\
\sum_{\Sigma}^{D}\end{array}$ & 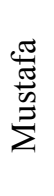 & 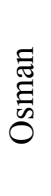 & $\stackrel{\grave{\Phi}}{:}$ & 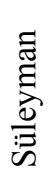 & 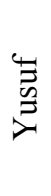 & 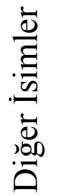 & $\frac{\Xi}{\frac{\Xi}{2}}$ \\
\hline Cami-i Cedid Mh. & 7 & 7 & 1 & 3 & 6 & 6 & 6 & 13 & 10 & 6 & 1 & - & 1 & 9 & 76 \\
\hline Cami-i Atik Mh. & 7 & 6 & 4 & 5 & 3 & 3 & 2 & 8 & 4 & 4 & 2 & 2 & 3 & 16 & 74 \\
\hline Makbulağa Mh. & 15 & 18 & 9 & 6 & 12 & 12 & 6 & 31 & 11 & 5 & 7 & 9 & 3 & 22 & 168 \\
\hline Hatibsüleyman Mh. & 3 & 4 & 2 & 4 & 2 & 3 & 1 & 11 & 6 & 2 & - & 6 & 3 & 3 & 52 \\
\hline Mecdeddin Mh. & 6 & 4 & - & 4 & 3 & 1 & 4 & 12 & 6 & 3 & - & 6 & 3 & 7 & 59 \\
\hline Has Balaban Mh. & 4 & 7 & 5 & 4 & 8 & 3 & 1 & 8 & 7 & 1 & 3 & 2 & 1 & 13 & 67 \\
\hline Karadayı Mh. & 3 & 1 & 3 & 3 & 4 & 2 & 2 & 5 & 2 & - & 1 & - & 1 & 2 & 29 \\
\hline
\end{tabular}




\begin{tabular}{|l|c|c|c|c|c|c|c|c|c|c|c|c|c|c|c|}
\hline İskender Çelebi Mh. & 6 & 7 & 2 & 5 & 8 & 2 & 1 & 10 & 5 & 3 & & 3 & 3 & 2 & 57 \\
\hline Baba Doğan Mh. & 6 & 4 & 3 & 5 & 3 & 5 & 5 & 14 & 8 & 6 & 3 & 3 & 1 & 8 & 75 \\
\hline Tuzcular Mh. & 9 & 9 & 4 & 6 & 6 & 7 & 2 & 17 & 3 & - & & 1 & 2 & 5 & 72 \\
\hline Çullah Kara Mh. & 5 & 4 & - & - & - & 2 & 1 & 9 & 2 & - & 1 & 1 & & 3 & 29 \\
\hline Ahi Yusuf Mh. & 4 & 3 & 2 & 3 & 4 & 1 & 2 & 4 & 4 & 1 & & - & 3 & 5 & 38 \\
\hline Ahi Kızı Mh. & 1 & 2 & 3 & 2 & 6 & 1 & 4 & 9 & 7 & 1 & 2 & 3 & 1 & 3 & 45 \\
\hline Toplam & 76 & 76 & 38 & 50 & 65 & 48 & 37 & 151 & 75 & 32 & 20 & 36 & 25 & 112 & 841 \\
\hline
\end{tabular}

Kaynak: BOA.,NFS.d. 3190

Yukarıda yer alan tablo, mahallelerde sıklıkla kullanıldığı tespit edilen isimler dikkate alınarak oluşturulmuş olup, tüm mahallelerdeki toplamları 20'nin altında kalan isimler ise "Diğer Issimler" grubuna dahil edilmiştir.

Tabloda yer alan isimlerden de görüleceği üzere, erkek nüfus için yaygın olarak kullanılan 13 isim tespit edilmiştir. Bu isimler günümüzde de sıklıkla kullanılan ve geleneksel Türk-İslam unsurlarını yansıtan isimlerdir. Sıklıkla kullanıldığı tespit edilen bu isimler içinde \% 18'lik bir payla, kullanımı en yaygın olan isim Mehmed ismidir. Ardından ise \% 9'luk bir payla Ahmed, Ali ve Mustafa isimlerinin geldiği görülmektedir. Kullanımı yaygın olan isimler sıralamasında en düşük payı ise \%'3'lük payla Yusuf ve \%2'lik payla Ömer isimleri oluşturmaktadır. Görüldüğü üzere, kullanılan isimler genel olarak Peygamber ve Dört Halife isimlerinden oluşmaktadır. Buradan hareketle, isim koymada dini inancın etkili olduğu söylenebilir.

Tüm mahallelerdeki toplamları 20'nin altında kalan ve "Diğer İsimler" grubuna dahil edilen isimlerin toplamları 112 olup, ortalamadaki payları ise \% 13'tür. Tespit edilen toplamlariyla bu isimler: 2 Hamza, 1 Ataullah, 12 Bekir, 1 Memiş, 4 Mahmud, 5 Salih, 14 Abdullah, 1 Bestuni, 1 Halifi, 3 Abdülkadir, 14 Abdurrahman, 1Aliyyürrıza, 1 Kanber, 1 Kenan, 2 Abdi, 1 Numan Naim, 1 Cevad, 2 Emin, 2 Veli, 1 Yunus, 1 Riza, 1 Mercan, 1 Cafer, 1 Abdülnasır, 1 Mekki, 1 Abdülhamid, 1 Abdülcevad, 1 Abdül, 2 İsa, 1 Civelek, 1 Nebi, 1 Hafiz, 1 Abdülfettah, 1 Sadullah, 2 Ramazan, 1 Matar, 1 Kadri, 1 Sabbah, 1 Hamid, 2 Abdülbaki, 1 Himmet, 1 Feyzullah, 2 Murad, 1 Mümin, 2 Eyyub, 1 Abdülkerim, 1 Şakir, 2 Musa, 1 Menamin, 1 Selami, 1 Ziya, 1 Seyyid, 1 Hızır, 1 İmam, 1 Vahid, 1 Hanifi şeklinde sıralanabilir. Görüldüğü gibi, bu isimler de Türk-İslam unsurlarını yansıtan isimler olup Mekki, Matar, Civelek ve Sabbah gibi isimler haricindekilerin çoğu, yine günümüzde de kullanılan isimlerdendir.

Defter kayıtları lakap kullanımı açısından incelendiğinde, babanın soyuna dayanan kullanım örnekleri olarak; Tavil, Karaüzüm ve Zavallığlu lakapları tespit edilmiştir. Memleket, meslek, fiziksel bir engel veya benzeri özellikler ile ilgili olan lakaplar olarak ise; Müezzin, Hafız, Hacı, Derviş, Dersiam, Türbedar, Seyyid, Molla, İmam, Şeyh, Zenci, Şişman, Çolak, Yekçeşm, Sağır, Duac1, Peştemalci, Pazarbaşı, Saatci, Mübaayac1, Hamal, Edirneli, Bağdadi, Tokadlı, Hamidli, İskenderani, Burdurlu, Anamurlu, Ünyeli, İstanköylü, Bursalı, Karadeniz Ereğlisinden, Alaiyyeli, Yesli, Tosyalı, Mısırlı, Trabzoni, Rodoslu, Çanakkalalı, Gazzeli, Giridli, Konyalı, İznikmidli, Mihaliçli, Marleli lakaplarına rastlanmıştır. Buna göre; memleket, meslek, fiziksel bir engel veya benzeri özellikler ile ilgili olan lakapların kullanımının daha ağırlıklı olduğu söylenebilir.

\subsubsection{Erkek Nüfusun Yetişkin ve Genç Nüfus Olarak Dağılımı}

1830 senesinde Antalya'da yapılan ilk modern genel nüfus sayımına göre, Antalya Kaleiçi'ndeki 13 mahalleye ait defter kayıtlarında, mevcut erkek nüfusun yaş bilgilerine de yer verilmiştir. 
Sayıma tabi tutulan yetişkin ve genç erkek nüfusun yaşları defterde, "Yevm (gün), mah(ay) ve $\sin (y l l)$ " olarak kaydedilmiştir.

Antalya Kaleiçi'ndeki 13 mahalleye ait nüfus kayıtlarından sağlanan yaş verileri, yetişkin ve genç erkek nüfus olarak tasnif edilmiş olup, elde edilen sonuçlara aşağıdaki tabloda yer verilmiştir. Yetişkin ve genç erkek nüfus tasnifinde, 15 yaş esas alınarak bir tasnif yapılmıştır. Yapılan tasnife göre tabloda; "15 yaş üzerinde olanlar" yetişkin erkek nüfus, "0-15 yaş arasında olanlar" genç erkek nüfus içinde değerlendirilmiştir.

Tablo 7. 1830 Tarihli Nüfus Defteri Verilerine Göre Antalya Kaleiçi'nde Bulunan Mahallelerdeki Yetişkin ve Genç Erkek Nüfusun Dağılımı

\begin{tabular}{|l|l|c|c|c|c|c|}
\hline \multicolumn{2}{|l|}{ Mahalle İsimleri } & $\begin{array}{c}\text { Yetişkin Nüfus } \\
(15 \text { yaş üzeri) }\end{array}$ & $\begin{array}{c}\text { Yüzde } \\
(\%)\end{array}$ & $\begin{array}{c}\text { Genç Nüfus } \\
(0-15 \text { yaş arası })\end{array}$ & $\begin{array}{c}\text { Yüzde } \\
(\%)\end{array}$ & Toplam \\
\hline 1 & Mahalle-i Cami-i Cedid & 43 & 57 & 33 & 43 & 76 \\
\hline 2 & Mahalle-i Cami-i Atik & 50 & 68 & 24 & 32 & 74 \\
\hline 3 & Mahalle-i Makbulağa & 99 & 59 & 69 & 41 & 168 \\
\hline 4 & Mahalle-i Hatib Süleyman & 32 & 62 & 20 & 38 & 52 \\
\hline 5 & Mahalle-i Mecdeddin & 32 & 54 & 27 & 46 & 59 \\
\hline 6 & Mahalle-i Has Balaban & 46 & 69 & 21 & 31 & 67 \\
\hline 7 & Mahalle-i Karadayı & 17 & 59 & 12 & 41 & 29 \\
\hline 8 & Mahalle-i İskender çelebi & 30 & 53 & 27 & 47 & 57 \\
\hline 9 & Mahalle-i Baba Doğan & 44 & 59 & 31 & 41 & 75 \\
\hline 10 & Mahalle-i Tuzcular & 36 & 50 & 36 & 50 & 72 \\
\hline 11 & Mahalle-i Çullah Kara & 14 & 48 & 15 & 52 & 29 \\
\hline 12 & Mahalle-i Ahi Yusuf & 25 & 66 & 13 & 34 & 38 \\
\hline 13 & Mahalle-i Ahi Kızı & 22 & 49 & 23 & 51 & 45 \\
\hline Toplam & 490 & 58 & 351 & 42 & 841 \\
\hline
\end{tabular}

Kaynak: BOA.,NFS.d. 3190

Tablo verilerine göre; "15 yaş üzerinde olanlar" içinde tasnif edilen yetişkin erkek nüfusun tüm mahallelerdeki toplamı 490; "0-15 yaş arasında olanlar" içinde tasnif edilen genç erkek nüfusun tüm mahallelerdeki toplamı ise 351 'dir. Yüzde oran olarak değerlendirildiğinde ise, toplam erkek nüfusun \%58'ini yetişkin nüfusun, $\% 42$ 'sini genç nüfusun oluşturduğu görülmektedir.

Tablo verileri mahalleler itibariyle değerlendirilirse; yetişkin erkek nüfusun en fazla olduğu yer; 99 kişi ile Makbulağa Mahallesi'dir. Ardından ise, 50 kişi ile Cami-i Atik ve 46 kişi ile Has Balaban mahalleleri gelmektedir. Yetişkin erkek nüfusun en az olduğu yer ise; 14 kişi ile Çullah Kara Mahallesi olup ardından, 17 kişi ile Karadayı Mahallesi gelmektedir. Yetişkin erkek nüfusun mahallelerdeki yüzde olarak dağılımında ise, \%69'luk bir payla Has Balaban mahallesi en yüksek orana sahipken, \%48'lik payla Çullah Kara Mahallesi'nin en düşük orana sahip olduğu görülmektedir.

En fazla genç erkek nüfus ise, 69 kişi ile Makbulağa Mahallesi'nde bulunmakta olup ardından ise, 36 kişi ile Tuzcular ve 33 kişi ile Cami-i Cedid mahalleleri gelmektedir. Genç erkek nüfusun en az olduğu yerler ise; 12 kişi ile Karadayı ve 13 kişi ile Ahi Yusuf mahallelerdir. Genç erkek nüfusun mahallelerdeki yüzde olarak dağılımında ise, \%52'lik bir payla Çullah Kara mahallesi en yüksek orana sahipken, \%31'lik bir payla Has Balaban Mahallesi en düşük orana sahiptir. 
Görüldüğü üzere, mahallelerdeki erkek nüfus sayısı dolayısıyla, yetişkin ve genç erkek nüfusun en fazla ve en düşük olduğu yerler, kişi sayısı ve yüzde dağılım olarak farklılık göstermektedir.

Yine tablo verilerine göre, yetişkin ve genç erkek nüfus sayısı arasındaki farkın en fazla olduğu yerler; 30 kişi ile Makbulağa Mahallesi ve 26 kişi ile Cami-i Atik mahallesidir. Yetişkin ve genç erkek nüfus sayısı arasındaki farkın en az olduğu yerler ise; 1 kişi ile Culahkara ve Ahi Kızı mahalleleridir. Tuzcular Mahallesi'nde ise, yetişkin ve genç erkek nüfus sayısının eşit olduğu görülmektedir.

Nüfus kayıtları verilerine göre; 60 yaş ve 60 yaşın epeyce üstünde olan kişilerin varlığ 1 da tespit edilmiş olup, yetişkin erkek nüfus içinde değerlendirdiğimiz bu yaşlı nüfusun mahalleler itibariyle dağılımı aşağıdaki tabloda gösterilmiştir.

Tablo 8. 1830 Tarihli Nüfus Defteri Verilerine Göre Antalya Kaleiçi Mahallelerinde Mevcut Erkek Nüfus İçindeki 60 Yaş ve Üzerinde Olan Kişilerin Dağılımı

\begin{tabular}{|c|c|c|c|}
\hline \multicolumn{2}{|r|}{ Mahalle İsimleri } & \multirow{2}{*}{$\begin{array}{l}\quad 60 \text { Yaşve Üzerinde Olan Kişi Sayısı } \\
75 \text { yaşında } 1 \text { kişi, } 70 \text { yaşında } 1 \text { kişi, } 65 \text { yaşında } 1 \text { kişi, } \\
63 \text { yaşında } 1 \text { kişi }\end{array}$} & \multirow{2}{*}{$\begin{array}{c}\text { Toplam } \\
\text { (Kişi) } \\
4\end{array}$} \\
\hline 1 & Mahalle-i Cami-i Cedid & & \\
\hline 2 & Mahalle-i Cami-i Atik & 70 yaşında 3 kişi, 65 yaşında 1 kişi, 60 yaşında 2 kişi & 6 \\
\hline 3 & Mahalle-i Makbulağa & 70 yaşında 4 kişi, 65 yaşında 2 kişi, 60 yaşında 3 kişi & 9 \\
\hline 4 & $\begin{array}{l}\text { Mahalle-i Hatib } \\
\text { Süleyman }\end{array}$ & $\begin{array}{l}80 \text { yaşında } 1 \text { kişi, } 70 \text { yaşında } 1 \text { kişi, } 65 \text { yaşında } 1 \text { kişi, } \\
60 \text { yaşında } 2 \text { kişi }\end{array}$ & 5 \\
\hline 5 & Mahalle-i Mecdeddin & $\begin{array}{l}80 \text { yaşında } 1 \text { kişi, } 70 \text { yaşında } 1 \text { kişi, } 65 \text { yaşında } 3 \text { kişi, } \\
60 \text { yaşında } 1 \text { kişi }\end{array}$ & 6 \\
\hline 6 & Mahalle-i Has Balaban & 70 yaşında 2 kişi, 65 yaşında 1 kişi, 60 yaşında 1 kişi & 4 \\
\hline 7 & Mahalle-i Karadayı & $\begin{array}{l}75 \text { yaşında } 1 \text { kişi, } 65 \text { yaşında } 1 \text { kişi, } 63 \text { yaşında } 1 \text { kişi, } \\
60 \text { yaşında } 1 \text { kişi }\end{array}$ & 4 \\
\hline 8 & $\begin{array}{l}\text { Mahalle-i İskender } \\
\text { Çelebi }\end{array}$ & $\begin{array}{l}70 \text { yaşında } 1 \text { kişi, } 65 \text { yaşında } 1 \text { kişi, } 63 \text { yaşında } 1 \text { kişi, } \\
60 \text { yaşında } 3 \text { kişi }\end{array}$ & 6 \\
\hline 9 & Mahalle-i Baba Doğan & 90 yaşında 1 kişi, 80 yaşında 1 kişi, 60 yaşında 1 kişi & 3 \\
\hline 10 & Mahalle-i Tuzcular & 110 yaşında 1 kişi, 65 yaşında 1 kişi, 60 yaşında 4 kişi & 6 \\
\hline 11 & Mahalle-i Çullah Kara & $\begin{array}{l}75 \text { yaşında } 1 \text { kişi, } 70 \text { yaşında } 1 \text { kişi, } 65 \text { yaşında } 1 \text { kişi, } \\
60 \text { yaşında } 1 \text { kişi }\end{array}$ & 4 \\
\hline 12 & Mahalle-i Ahi Yusuf & 60 yaşında 1 kişi & 1 \\
\hline 13 & Mahalle-i Ahi Kızı & 60 yaşında 1 kişi & 1 \\
\hline \multicolumn{3}{|c|}{ Toplam } & 59 \\
\hline
\end{tabular}

Kaynak: BOA.,NFS.d. 3190

Tablo verilerine göre; 60 yaş ve üzerinde olan kişilerin toplamı 59 olup, tüm erkek nüfus toplamının \%7'sini oluşturmaktadır. 60 yaş ve üzerindeki kişi sayısının en fazla olduğu yer 9 kişinin bulunduğu Makbulağa Mahallesi; en az olduğu yerler ise 1'er kişinin bulunduğu Ahi Yusuf ve Ahi Kızı mahalleleridir. Yaş itibariyle ise tüm mahalleler toplamında sırasıyla; 60 yaşında olanların 21 kişi, 70 yaşında olanların 14 kişi, 65 yaşında olanların 13 kişi, 63, 75 ve 80 yaşında olanların her birinin 3'er kişi, 90 ve 110 yaşında olanların her birinin ise 1'er kişi olduğu tespit edilmiştir. 60 yaş ve 60 yaşın epeyce üzerindeki yaş dilimlerinde bulunanların varlığ 1 , o döne- 
min koşullarında da uzun yaşamın mümkün olabildiğinin bir göstergesi olarak kabul edilebilir.

\subsubsection{Nüfusun Mesleki Dağılımı}

1830 tarihli Antalya genel nüfus sayım defterine göre; Antalya Kaleiçi'nde tespit edilen 13 mahalleye ait kayıtlarda, nüfus sayımının askeri amaçla yapılması dolayısıyla, sayımı yapılan her kişinin mesleği belirtilmemiş olmakla birlikte, yine de mesleği belirtilenlere ait verilerden bir tespite ulaşılabilmektedir. Elde edilen sonuçlar aşağıdaki tabloda yer almaktadır.

Tablo 9. 1830 Tarihli Nüfus Defteri Verilerine Göre Antalya Kaleiçi’nde Bulunan Mahallelerde Tespit Edilen Meslekler

\begin{tabular}{|c|c|c|c|}
\hline Meslek & Sayı & Meslek & Sayı \\
\hline Amele & 1 & Helvacı & 1 \\
\hline Asker & 57 & Hizmetkar & 1 \\
\hline Aşc1 & 1 & İmam & 14 \\
\hline Attar & 4 & Kadayıfcı & 1 \\
\hline Bağçevan & 1 & Kahveci & 6 \\
\hline Bakkal & 4 & Kaptan & 2 \\
\hline Berber & 1 & Kasap & 1 \\
\hline Bezistanc1 & 1 & Kavas & 1 \\
\hline Bezzaz & 19 & Kayıkcı & 2 \\
\hline Boyacı & 1 & Kazzaz & 3 \\
\hline Börekci & 1 & Kileci & 2 \\
\hline Camc1 & 1 & Kiracı & 3 \\
\hline Cami süpürücüsü & 1 & Muallim-i sıbyan & 3 \\
\hline Ciltci & 1 & Muhzir & 1 \\
\hline Çerçi & 4 & Mutaf & 3 \\
\hline Çıracı & 2 & Mübaayacı & 1 \\
\hline Çizmeci & 2 & Müezzin & 7 \\
\hline Çubukcı & 2 & Naib & 1 \\
\hline Çulah & 91 & Nakib & 1 \\
\hline Debbağ & 40 & Neccar & 1 \\
\hline Debbağ şakirdi & 3 & Oturakc1 & 1 \\
\hline Dellak & 1 & Pabucc1 & 1 \\
\hline Deveci & 4 & Pazar ağası / başı & 2 \\
\hline Dikici & 1 & Saatci & 1 \\
\hline Doğramacı & 2 & Sebzeci & 3 \\
\hline Duac1 & 1 & Semerci & 3 \\
\hline Duhanc1 & 2 & Serrac & 1 \\
\hline Dükkancı & 7 & Seyis & 2 \\
\hline Dülger & 1 & Terzi & 1 \\
\hline Ekmekci & 1 & Timurcı (Demirci) & 4 \\
\hline
\end{tabular}




\begin{tabular}{|l|c|c|c|}
\hline Eskici & 1 & Tüccar & 27 \\
\hline Habbaz & 12 & Türbedar & 1 \\
\hline Hafız & 5 & Yağcı & 10 \\
\hline Hammal & 6 & Yapucı & 1 \\
\hline Hamamcı & 1 & Yemenici & 1 \\
\hline Hatip & 1 & Toplam & 398 \\
\hline
\end{tabular}

Kaynak: BOA.,NFS.d. 3190

Tablo verilerine göre, Antalya Kaleiçi'ndeki 13 mahallede, 841'i buluna toplam erkek nüfus içinde belli bir meslekle iştigal olanların sayısı 398 kişidir. Meslek çeşitliliği bakımından, 71 meslek çeşidi tespit edilmiştir. Buradan hareketle, Antalya'daki sosyo-ekonomik hayatın belli bir iş bölümü çerçevesinde, kendi kendine yeten bir yapı sergilediği söylenebilir.

Meslekler içinde özellikle çulah (91), asker (57) ve debbağ (40) sayısının diğer mesleklere oranla daha fazla olduğu görülmektedir. Müstahfız, tabur askeri, sipahi süvarisi, sipahi tekaüdi, humbaracı tekaüdi, humbaracı sipahisi, topc1-i kala, bevvab-1 kala göreviyle kaydedilenlerin tamamı, asker gurubuna dahil edilmiş olup asker sayısının fazlalığı, Antalya Kalesi'nin varlığına dayandırılabilir. Yine, çulah ve debbağ sayısının fazlalığını da dokumacılık ve deri işlemeciliğinin Antalya' daki potansiyeline dayandırmak mümkündür. Bu potansiyelin, Antalya coğrafyasına uyum sağlayan keçi varlığı ile yakından ilişkili olduğu düşünülebilir. Mahalleler içinde Baba Doğan Mahallesi (12) asker sayısının, Makbulağa Mahallesi (25) çulah sayısının ve Ahi Kızı Mahallesi (14) debbağ sayısının en fazla olduğu mahalleler arasında yer almaktadır ki; bu durum mahalleler arasındaki mesleki uzmanlaşmanın bir göstergesi olarak kabul edilebilir.

Herhangi bir mesleği olmayıp, çalışmayan kesim içinde yer alan kişi sayısı ise 57 kişi olarak tespit edilmiştir. Çalışmayan kesim içinde; yetim, talib (talebe), meczub (deli, mecnun), alil (kör, sakat), bî-zeban (dilsiz) olanlar ve birilerine tabi bulunanlar yer almakta olup bu kişiler, başkalarının yardımlarıyla geçinen kişilerdir. Bu durumun, çalışmayan kesimin toplumun dışına itilmediğini ve toplum içindeki mevcut dayanışmayı gösterdiğini söyleyebiliriz.

\section{Sonuç}

Osmanlı İmparatorluğu'nda, modern anlamda yapılan ilk genel nüfus sayımı, 1830'da başlayıp 1831 'de tamamlanmıştır. Bu çalışmada da, Antalya'ya ait ilk modern genel nüfus sayım verileri doğrultusunda, Antalya'daki yerleşimin çekirdek birimi olarak, Kaleiçi mahallelerindeki mevcut müslüman erkek nüfusun demografik açıdan bir profili elde edilmeye çalışılmıştır. Böylelikle, Başbakanlık Osmanlı Arşivleri tasnifinde 3190 numara ile yer alan ve Osmanlı Türkçesi ile yazılmış olan Antalya'ya ait ilk genel nüfus sayım verileri, sadece nüfus toplamları açısından değil, diğer demografik unsurlar açısından da ortaya konulmuştur.

Mevcut sayım verilerine göre; Antalya merkez kazasında 26 köy ve 34 mahalle sayıma tabi tutulmuş olup, bu mahallelerden 13'ü kaleiçinde (derun-i kal'a), 21'i ise kalenin dışında (haric-i kal'a) yer alan mahallelerdir. Bu veriler, Antalya'daki yerleşimin kalenin dişına doğru genişlediğinin de bir göstergesi niteliğindedir.

26 köy ve 34 mahallenin sayım sonuçlarını içeren defter kayıtlarında, her yerleşim birimine ait toplam sayım sonucu, o yerleşim biriminin sayım kaydı sonunda verilmekte olup, en sonda ise genel toplam verilmektedir. Bununla birlikte, ilk nüfus sayımını halkın tereddütle karşılaması ve her vilayet, liva ve kazaya hükümetin teklifler yükleyeceği şayiasından dolayı, halkın çoğu yerde erkek nüfus adedini daha az göstermek istemesinin, az ya da çok, mevcut sayım 
sonuçlarını etkilemiş olabileceği göz ardı edilmemelidir.

Sadece müslüman erkek nüfusun sayıldığı Antalya'daki bu sayımda, kadın ve gayr-i müslim nüfusun sayılmamış olması, sayımın askeri amaçla yapıldığı düşüncesini kuvvetlendirmektedir. Kayıtların başlangıcında öncelikle, Osmanlı toplumunda önderlik vasfına sahip olan mahallenin imamı ve yakınlarının kaydedildiği görülmektedir. Kişiler, babalarının isimleriyle, fiziksel özellikleri (sakal, boy, fiziksel engel), yaş, lakap ve mesleki bilgilerine yer verilerek kaydedilmişlerdir.

$\mathrm{Bu}$ veriler 1şığında, Osmanlı İmpraratorluğu'nun modern anlamda yapılan ilk genel nüfus sayımında, Antalya Kaleiçi'nde tespit edilen 13 mahalleye ait erkek nüfus verisi, demografik açıdan değerlendirilerek ortaya konulmuştur. Yapılacak yeni çalışmalarla, bu konudaki bilgi birikimimizin bir üst seviyeye taşınması en büyük temennimizdir. 


\section{KAYNAKÇA}

Acun, F., (2005). "Osmanlı Şehirlerinde Devlet ve Sivil Toplum”. Sivil Toplum Dergisi, 3/10, 51-59.

Armağan, L., (2005). "XVI. Yüzyılda Antalya". Ankara Üniversitesi Dil ve Tarih-Coğrafya Fakültesi Tarih Bölümü Tarih Araștırmaları Dergisi, 24/38, 93-111.

Barkan, Ö. L. (2000). “Türkiye'de İmparatorluk Devirlerinin Büyük Nüfus ve Arazi Tahrirleri ve Hakana Mahsus İstatistik Defterleri (I)". Haz.: Hüseyin Özdeğer. Osmanlı Devleti'nin Sosyal ve Ekonomik Tarihi/Tetkikler-Makaleler, I, 175-214. İstanbul: İ.Ü.İ.F. Dilek Ofset-Matbaacılık.

Bingöl, S., (2004). "İstanbul'da 1829 Nüfus Sayımı ve Bazı Mahallelerin Müslüman Nüfusu Üzerine Bir İnceleme". Ankara Üniversitesi Dil ve Tarih-Coğrafya Fakültesi Tarih Bölümü Tarih Araştırmaları Dergisi, 23/36, 43-60.

Devellioğlu, F. (1999). Osmanlıca-Türkçe Ansiklopedik Lugat. 16. Baskı, Ankara: Aydın Kitabevi Yayınları.

Doğan, A., (2012). 19. Yüzyılda Teke Sancağı Antalya Merkez Kazası'nın Sosyo-Ekonomik Yapısı. Yayınlanmamış Doktora Tezi. Marmara Üniversitesi, Sosyal Bilimler Enstitüsü, İstanbul.

Elibol, N., (2007). “Osmanlı İmparatorluğu'nda Nüfus Meselesi ve Demografi Araştırmaları”. Süleyman Demirel Üniversitesi, Iktisadi ve İdari Bilimler Fakültesi,12/2, 135-160.

Emecen, F., (1991). “Antalya” maddesi. Türkiye Diyanet Vakfi İslam Ansiklopedisi, Cilt-3, 232. İstanbul.

Erten, S. F., (1940). Antalya Vilayeti Tarihi. İstanbul: Tan Matbaası.

Karaca, B., (2002). XV. ve XVI. Yüzylllarda Teke Sancağı. 1. Baskı. Isparta: Fakülte Kitabevi.

Karal, E. Z., (1943). Osmanlı Imparatorluğu'nda İlk Nüfus Sayımı 1831. Ankara: Başvekalet İstatistik Umum Müdürlügü Yayını.

Moğol, H., (1990). Şer'iyye Sicillerine Göre XIX. Yüzyılın İlk Yarısında Antalya. Yayınlanmamış Doktora Tezi. Ankara Üniversitesi, Sosyal Bilimler Enstitüsü, Ankara.

Özdemir, R., (1994). "Osmanlı Döneminde Antalya'nın Fiziki ve Demografik Yapısı (1800-1867)". XI. Türk Tarih Kongresi, (Ankara: 5-9 Eylül 1990), Kongreye Sunulan Bildiriler IV. Cilt, 1369-1405. Ankara: Türk Tarih Kurumu Basımevi.

Tabakoğlu, A., (2003). Türk İktisat Tarihi. İstanbul: Dergah Yayınları.

Tekindağ, Ş., (1979). "Teke-Oğulları" maddesi. MEB İslam Ansiklopedisi, 12/1, 131. İstanbul: Milli Eğitim Basımevi.

Uzunçarşılı, İ. H., (1969). Anadolu Beylikleri ve Akkoyunlu, Karakoyunlu Devletleri. Ankara: Türk Tarih Kurumu Basımevi.

\section{Bașbakanlık Osmanlı Arșivi Belgeleri}

Nüfus Defteri: BOA., NFS. d. 3190

Sadaret Amedi Kalemi: BOA. A.AMD., 28-38, 3 Ocak 1851

Sadaret Mektubi, Meclis-i Vala: BOA. A.MKT.MVL., 38-16, 21 Ocak 1851; BOA, A.MKT.MVL., 11987, 12 Eylül 1860

Cevdet Askeriye: BOA, C.AS., 440-18313, 15 Kasım 1834

Hatt-1 Hümayun: BOA. HAT., 1625-66, 4 Mart 1840 